\title{
Challenges of Cardiopulmonary Bypass-A Review of the Veterinary Literature
}

\author{
Augusta Pelosi ${ }^{1}$, DVM, Diplomate ACVS, Lorel K. Anderson ${ }^{1}$, DVM, Jennine Paugh ${ }^{2}$, CCP, \\ Scott Robinson ${ }^{1}$, PBT, and George E. Eyster ${ }^{1}$, DVM, Diplomate ACVS \\ ${ }^{1}$ Small Animal Clinical Sciences, Michigan State University, East Lansing, MI and ${ }^{2}$ University of Michigan Mott's Children Hospital, Ann Arbor, MI
}

\author{
Corresponding Author \\ Augusta Pelosi, DVM, Diplomate ACVS, \\ G384 Small Animal Clinical Sciences, \\ Michigan State University, East Lansing, MI \\ 48824-1314 \\ E-mail: pelosiau@cvm.msu.edu \\ Received February 2011 \\ Accepted August 2011 \\ DOI:10.1111/j.1532-950X.2012.01008.x
}

\begin{abstract}
Cardiopulmonary bypass (CPB) has been used in veterinary medicine in experimental surgery and to address congenital and acquired diseases. We review the veterinary literature and expose common challenges of CPB in dogs and cats. Specifically, we describe the most specific elements of this technique in veterinary patients. The variety in animal size has made it difficult to standardize cannulation techniques, oxygenators, and priming volumes and solutions. The fact that one of the most common cardiovascular disorders, mitral valve disease, occurs predominantly in small dogs has limited the use of bypass in these patients because of the need for small, low prime oxygenators and pumps that have been unavailable until recently. Coagulation, hemostasis, and blood product availability have also represented important factors in the way CPB has developed over the years. The cost and the challenges in operating the bypass machine have represented substantial limitations in its broader use.
\end{abstract}

Cardiopulmonary bypass (CPB) has been used inconsistently since the late 1960 s in veterinary medicine to repair some of the most common intracardiac conditions that occur in dogs and cats. ${ }^{1-8}$ In animals, heart surgery has been performed in experimental settings and to address congenital and acquired conditions, such as ventricular septal defects, ${ }^{9,10}$ double chamber right ventricle, ${ }^{11}$ Tetralogy of Fallot, ${ }^{12,13}$ and mitral valve disease. ${ }^{14-16}$ When performing CPB in dogs and cats, there are important factors to consider: the different anatomy of the thoracic cavities requiring different types of cannulation, the dramatic variability in size and body conformation, the limited blood volume in small patients, the difference in coagulation and hemostasis compared with human patients, the limited availability of blood products, and the cost associated with their use.

We provide an overview of the literature related to the use of CPB for cardiac surgery in domestic animals. The data are extrapolated from the veterinary literature looking at cases where CPB was used to perform cardiac surgery.

\section{ANATOMY}

The thoracic cavity in domestic species resembles a truncated cone. The laterolateral compression in dogs and the anteroposterior compression in man and primates deter-

Presented in part at the ACVS Symposium, Seattle, WA, October 2010. mine several differences in the general surgical approach to the thoracic cavity. In dogs, the heart is located between the planes of the $3 \mathrm{rd}$ and 6 th intercostal spaces. The cardiac axis is inclined craniodorsally with the apex of the heart mildly to the left. Variations in the position of the heart within the thoracic cavity (Fig 1) are observed in different species and breeds or at different ages. For example, among dogs, the heart tends to be more vertical in the Doberman Pinscher, and it becomes progressively more horizontal in cats as they age. In addition to these considerations, the diseased heart can assume unusual inclinations and occupy different sections of the thoracic cavity because of enlargement of various cardiac chambers or secondary to generalized cardiomegaly.

To understand the anatomic challenges unique to animals, a review of the cardiac anatomy and associated thoracic structures is provided to facilitate orientation and identification of these details. Most of the cardiac surface is covered by the lungs except at the level of the cardiac notch (4th and 5th intercostal spaces), on the right side. On the surface of the heart, the coronary groove defines the separation between atria and ventricles, but it is absent at the level of the right ventricle. ${ }^{17}$ The Waterston's groove represents the embryologic separation between the left and the right atria. ${ }^{18}$ The interventricular grooves (sinusoidal and paraconal) are not obvious in small animals as they are in other mammals. ${ }^{17}$ However, the paraconal groove has an oblique direction on the cranioventral surface and the subsinusoidal groove delineates the separation of the ventricles on the caudodorsal surface. The coronary arteries run within the grooves. The left coronary artery is 


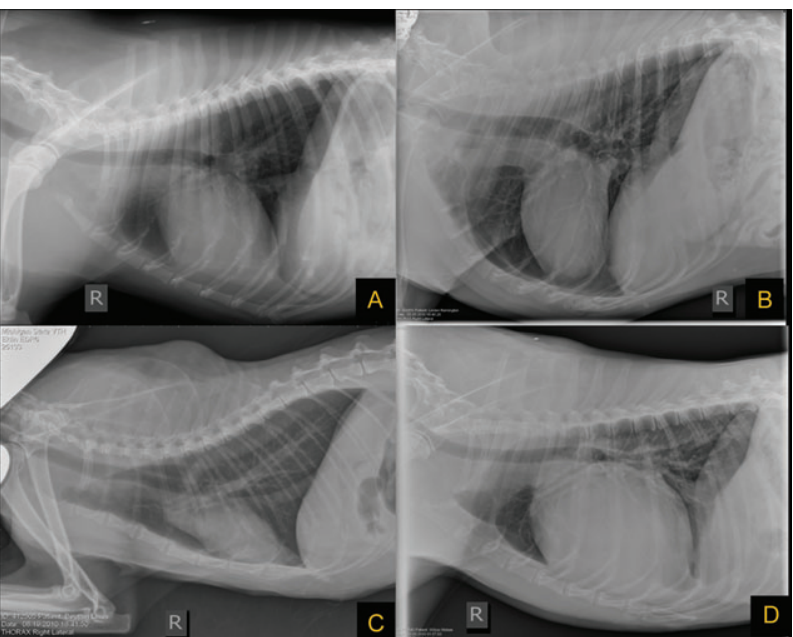

Figure 1 Variations in the position of the heart within the thoracic cavity are observed in different species and breeds or at different ages. The normal cardiac silhouette and position within the thoracic cavity $(A)$ can appear altered in specific breeds, such as Doberman Pinscher (B); it also becomes progressively more horizontal in cats as they age (C), and it assumes unusual inclinations and occupies different sections of the thoracic cavity because of enlargement of various cardiac chambers or secondary to generalized cardiomegaly (D). (Courtesy of Drs. Nathan Nelson and Joana Coelho).

usually the predominant one and gives off the paraconal interventricular branch (runs toward the apex in the paraconal interventricular groove) and the circumflex branch (runs on the caudal surface and ends as the subsinusoidal interventricular branch). The right coronary artery runs in a circumflex groove between the right atrium and ventricle. The venous system is satellite of the arterial system with the vessels draining into the coronary sinus and into the right atrium. ${ }^{17}$
The aorta originates from the fibrous cardiac skeleton, arises cranially toward the left as the aortic arch and ascending aorta and then curves dorsocaudally to form the descending aorta. The first branch of the aortic arch is the brachiocephalic trunk, which gives off the common carotid arteries and the right subclavian artery in dogs and cats. The second branch is the left subclavian artery. The main pulmonary artery lies on the left side of the thoracic cavity and it branches into left pulmonary artery (smaller) and right (larger branch, leaving the main pulmonary artery with $90^{\circ}$ angle, lying between the venae cavae). The cranial and caudal venae cavae lie to the right of the midline and enter the right atrium. The right azygous vein runs dorsally and enters the cranial vena cava before its termination. The left and right vagus nerves run at the level of the heart base, while the left and right phrenic nerves run over the pericardium at the level of the coronary groove. The left recurrent nerve originates from the left vagus at the level of the ductus or ligamentum arteriosum while the right recurrent nerve leaves the right vagus in the proximity of the right subclavian. ${ }^{17}$

In dogs, observation of the heart base structures is extremely limited from a median sternotomy. The left atrium can be approached from both a left and a right thoracotomy. Depending on the disease presentation, the approach may need to be modified. For example, in an infundibular type of stenosis or when the pulmonic stenosis has induced severe right ventricular hypertrophy, a median sternotomy rather than a left lateral approach may be necessary to obtain a complete observation of the right outflow tract. The femoral vessels are very superficial and easily approachable, while the approach to the carotid artery requires dissecting in a plane dorsal to the jugular vein, just adjacent to the trachea. The size of these vessels can affect the type of cannulae used; Table 1 shows the size of arterial and venous cannulae in relation to weight.

Table 1 Arterial and Venous Cannulae Used Based on Body Weight

\begin{tabular}{|c|c|c|c|}
\hline & Arterial & Venous & References \\
\hline$<10 \mathrm{~kg}$ & $\begin{array}{l}\text { 6-8 } \mathrm{Fr}(2-2.5 \mathrm{~mm}) \text { left or right carotid } \\
10 \mathrm{Fr}(3.3 \mathrm{~mm}) \text { straight carotid } \\
6 \mathrm{Fr}(2 \mathrm{~mm}) \text { carotid } \\
10 \mathrm{Fr}(3.3 \mathrm{~mm}) \text { left carotid } \\
1 \mathrm{~mm}(3 \mathrm{Fr}) \text { femoral } \\
2.5 \mathrm{~mm}(7.5 \mathrm{~mm}) \text { left femoral } \\
1.0-3.0 \mathrm{~mm}(3-9 \mathrm{Fr}) \text { femoral artery } \\
2-\mathrm{mm}(6 \mathrm{Fr}) \text { angled left femoral } \\
10-12 \mathrm{Fr}(3.3-4.0 \mathrm{~mm}) \text { carotid } \\
10-14 \mathrm{G} \text { left external iliac }\end{array}$ & $\begin{array}{l}\text { 8-10 Fr (2.5-3.3 mm) } \\
12 \mathrm{Fr}(4 \mathrm{~mm}) \text { cranial; } 14 \mathrm{Fr}(4.7 \mathrm{~mm}) \text { caudal VC } \\
14 \mathrm{Fr}(4.7 \mathrm{~mm}) \text { cranial; } 12 \mathrm{Fr}(4 \mathrm{~mm}) \text { caudal VC } \\
20 \mathrm{Fr}(6.7 \mathrm{~mm}) \text { single atrial } \\
\mathrm{NA} \\
14 \mathrm{Fr}(4.7 \mathrm{~mm}) 16 \mathrm{Fr}(5.3 \mathrm{~mm}) \text { (bicaval) } \\
\mathrm{NA} \\
8 \mathrm{~mm}(24 \mathrm{Fr}) \text { straight } \\
16 \mathrm{Fr}(5.3 \mathrm{~mm}) \text { bicaval } \\
28-32 \mathrm{G}\end{array}$ & $\begin{array}{l}\text { Kanemoto et al } \\
\text { Brourman et al } \\
\text { Soda et al } \\
\text { Boggs et al } \\
\text { Rosenkrantz et al }\left.\right|^{57} \\
\text { Shimizu et al } \\
\text { Tanaka et al }{ }^{3} \\
\text { Borenstein et al }\left.\right|^{5} \\
\text { Pullen et al69 } \\
\text { Lew et al }{ }^{27}\end{array}$ \\
\hline $10-20 \mathrm{~kg}$ & $\begin{array}{l}\text { 8-12 Fr (2.5-4 mm) left femoral } \\
8 \mathrm{~mm}(24 \mathrm{Fr}) \text { root aorta } \\
\mathrm{NA} \\
4 \mathrm{~mm}(12 \mathrm{Fr}) \text { aortic }\end{array}$ & $\begin{array}{l}\text { NA } \\
\text { NA } \\
18-24 \mathrm{Fr}(6-8 \mathrm{~mm}) \\
36 \mathrm{Fr}(12 \mathrm{~mm}) \text { single atrial }\end{array}$ & $\begin{array}{l}\text { Orton et al }\left.\right|^{12} \\
\text { Cook et al }{ }^{41} \\
\text { Takashima et al }{ }^{14} \\
\text { Liam et al }\end{array}$ \\
\hline$>21 \mathrm{~kg}$ & $\begin{array}{l}14 \mathrm{Fr}(4.7 \mathrm{~mm}) \text { left femoral } \\
20-22 \mathrm{Fr}(6.7-7.3 \mathrm{~mm}) \text { left femoral } \\
16-20 \mathrm{Fr}(5.3-6.7 \mathrm{~mm}) \text { left femoral }\end{array}$ & $\begin{array}{l}36-40 \mathrm{Fr}(12-13.3 \mathrm{~mm}) \text { single atrial } \\
32-40 \mathrm{Fr}(10.7-13.3 \mathrm{~mm})\end{array}$ & $\begin{array}{l}\text { Rohn et al }{ }^{55} \\
\text { Klement et al } \\
\text { Klement et al }\left.\right|^{33}\end{array}$ \\
\hline
\end{tabular}

VC, vena cava; NA, not available. 


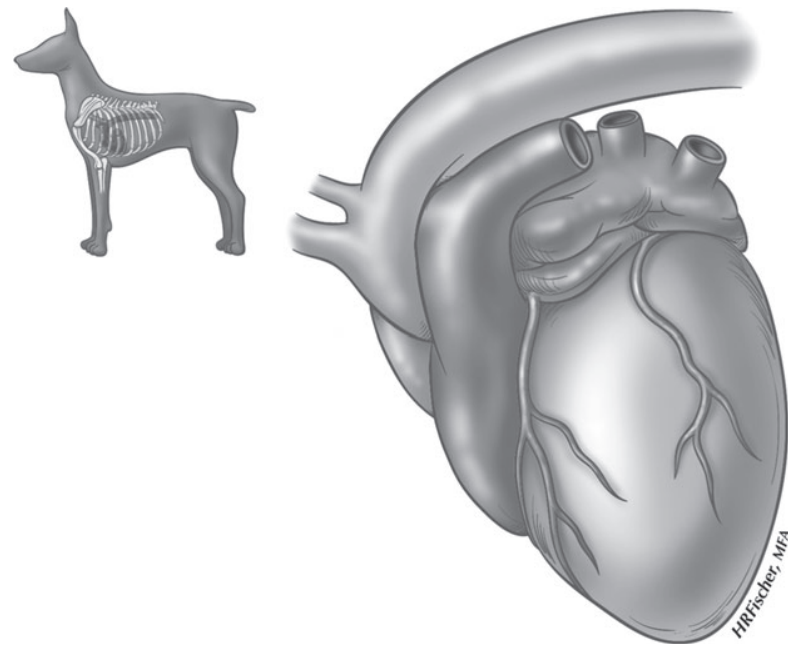

Figure 2 The cardiac structures from a left lateral thoracotomy. Lungs and other thoracic structures have been removed.

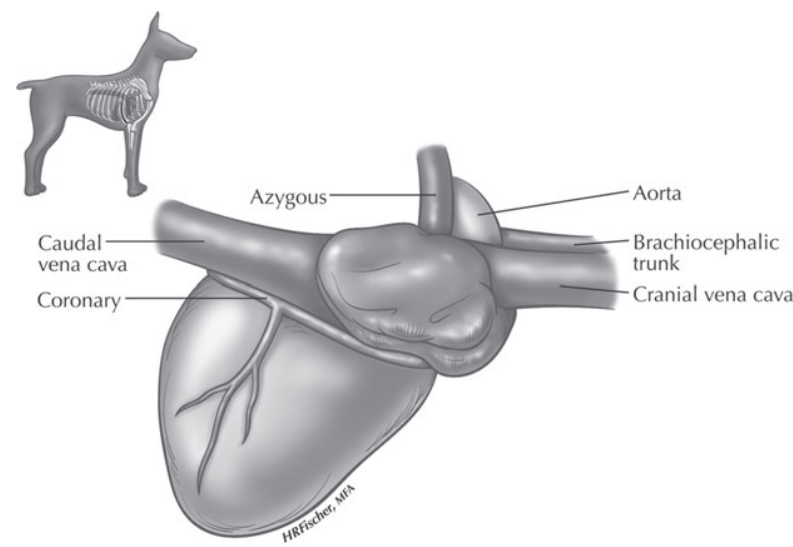

Figure 3 The cardiac structures seen through a right lateral thoracotomy. Lungs and other thoracic structures have been removed.

\section{CANNULATION}

In people, most procedures are performed from a median sternotomy with direct aortic cannulation for arterial access, and venous bicaval or single atrial cannulation. ${ }^{19}$ Historically, in domestic animals, left and right lateral thoracotomies (Figs 2,3) have been used more frequently than median sternotomy. Because of limited exposure and the surgical approaches necessary in different procedures, the cannulation has also been very variable. Arterial cannulation, independent of the surgical approach or the procedure, is primarily done through either the femoral or the carotid artery, while venous cannulation varies depending on the surgical approach (Table 2).

The arterial cannula represents the narrowest part of the extracorporeal circuit. High flow through the arterial cannula can lead to high-pressure gradients, high velocity flow, cavitation, and turbulence. ${ }^{19}$ Pressure gradients $>100 \mathrm{mmHg}$ are associated with hemolysis and protein denaturation. ${ }^{19}$ The jetting effect of small cannulae may cause damage to the interior aortic wall and/or aortic dissection. Several types of arterial cannulae have been evaluated to result in lower pressure gradients. The use of femoral artery cannulation is possible when aortic cannulation is ill advised. However, because of smaller size vessels, optimal flow may be compromised because of high-pressure gradients. This shortcoming can be palliated by using smaller and less-optimal cannulae. Vascular distal ischemia and retrograde dissection of the aorta are reported complications associated with femoral artery cannulation. ${ }^{19}$ Femoral arterial cannulation (Fig 4) can simplify the surgical field by decreasing the amount of instrumentation; however, the size of this vessel in domestic animals can limit the perfusion flow. Aortic cannulation (Fig 5) has been rarely used in dogs because of space limitation, difficulty in approaching the aortic arch from some thoracotomies in animals (right thoracotomy), and the anecdotal report of being more fragile than the human aorta. The aorta appears to be mechanically fragile when a cannula is inserted, but we lack histologic data to confirm something that appears to be anecdotal information. The aortic wall of dogs and mammals in general consists of the intimal, medial, and adventitial layers with the medial layer being the thickest. ${ }^{20}$ The aortic media is composed of concentric layers of uniform composition bounded by thick elastin lamellae. ${ }^{21}$ In mammals, the elastic laminae are well defined and the gap between them is usually filled by a single smooth muscle cell. ${ }^{22}$ Wolinsky et al investigated the relations among aortic thickness, medial thickness, medial architecture, and vessel wall tension in a comparative study of adult thoracic aortic wall in mammals. ${ }^{21}$ However, definitive conclusive data regarding fragility of the canine aorta cannot be extrapolated from this manuscript and further studies should be conducted.

Table 2 Reported Cannulation Types by Approach (Number of Veterinary Publications Where a Specific Type of Cannulation Is Reported)

\begin{tabular}{|c|c|c|c|c|c|c|c|c|c|c|c|c|}
\hline \multirow[t]{3}{*}{ Approach (no. of publications) } & \multicolumn{6}{|c|}{ Venous } & \multicolumn{6}{|c|}{ Arterial } \\
\hline & \multicolumn{3}{|c|}{ Single atrial } & \multirow[t]{2}{*}{ Bicaval } & \multirow{2}{*}{$\begin{array}{l}\text { Jugular/ } \\
\text { femoral }\end{array}$} & \multirow[t]{2}{*}{ NS } & \multirow[t]{2}{*}{ Aorta } & \multirow{2}{*}{$\begin{array}{l}\text { Right } \\
\text { femoral }\end{array}$} & \multirow{2}{*}{$\begin{array}{l}\text { Left } \\
\text { femoral }\end{array}$} & \multirow{2}{*}{$\begin{array}{c}\text { Any } \\
\text { femoral }\end{array}$} & \multirow[t]{2}{*}{ Carotid } & \multirow{2}{*}{$\begin{array}{l}\text { NS o } \\
\text { other }\end{array}$} \\
\hline & $\mathrm{S}$ & $\mathrm{D}$ & NS & & & & & & & & & \\
\hline Left thoracotomy (12) & 2 & 2 & 5 & 0 & 2 & 1 & 2 & 0 & 5 & 2 & 3 & \\
\hline Right thoracotomy (13) & & 1 & & 10 & & 3 & & & 5 & 3 & 3 & 2 \\
\hline Median sternotomy (19) & & & 3 & 13 & & 3 & 3 & 4 & 2 & 2 & 5 & 3 \\
\hline Not specified (4) & & & 1 & 3 & 1 & & & 2 & & 1 & 1 & \\
\hline
\end{tabular}

S, single stage; D, dual stage; NS, not specified. 


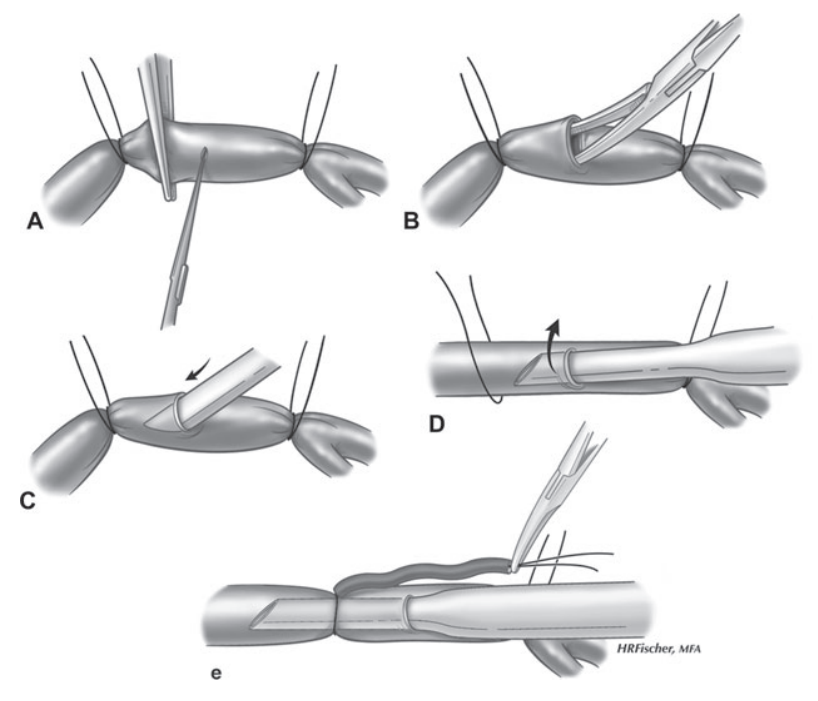

Figure 4 A peripheral arterial vessel (carotid or femoral artery) is easily approached and dissected. The adventitia is removed and the vessel is exposed. The vessel is distally ligated. While maintaining temporary proximal occlusion via silk suture or silastic tape, and transverse or longitudinal incision with an 11 blade is performed in the upper portion of the vessel (A). Dilation of the incision is obtained by using a vessel dilator or a forceps (B). The arterial cannula is introduced inside the lumen aiming toward the proximal portion of the vessel (C, D). The cannula is secured in placed by applying a red rubber tourniquet to the proximal suture and ligating the vessel to the tourniquets using silk suture $(E)$.
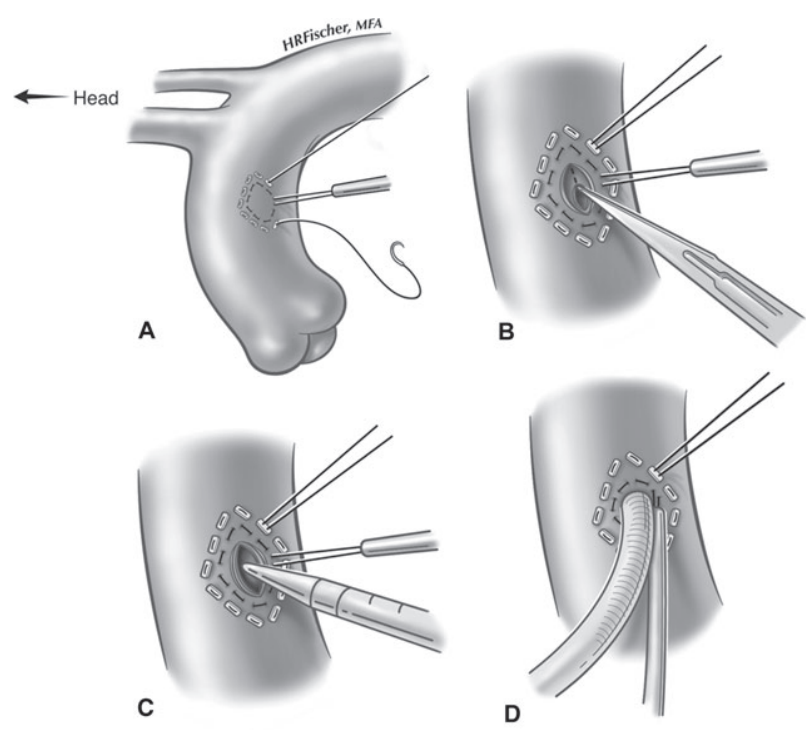

Figure 5 The aortic arch with the brachiocephalic trunk and the left subclavian artery are shown from a left-side window while applying a double purse string suture lines for aortic cannulation (A). A stabbed incision is performed with an 11 blade $(B, C)$; an arterial cannula is introduced within the lumen, paying attention to avoid dissection of the vessel and proper placement to perfuse the cranial and caudal compartments (D).

\section{CPB FLOW AND HYPOTHERMIA}

In the reviewed literature, the average $\mathrm{CPB}$ flow, independent of weight and thermic conditions, is $77.1 \pm 22.9$ $\mathrm{mL} / \mathrm{kg} / \mathrm{min}$.

The first use of hypothermia is reported in the late 1950s where in experimental dogs it was used to investigate survival factors in hypothermic conditions. ${ }^{22} \mathrm{Hy}-$ pothermia is used to provide organ and myocardial protection, minimize cell trauma, and reduce pump flow. ${ }^{23}$ By lowering the temperature of the blood, the metabolic rate and oxygen consumption is reduced along with preservation of cell membranes. Hypothermia helps to preserve phosphate stores and reduces neurotransmitter release. ${ }^{23}$ By reducing neurotransmitter release during ischemia, the opening of calcium channels and subsequent activation of destructive enzymatic systems would by attenuated, thus reducing calcium entry into the cell and restricting cell membrane permeability. ${ }^{23}$ Respiratory physiology is particularly affected by lowering body temperature. Compared to normothermic conditions, the solubility of gases increases, while the content of the gas in a solution remains constant. Therefore, the partial pressure of gases dissolved in the blood is also decreased making more oxygen available. The oxygen-hemoglobin dissociation curve undergoes a left shift resulting in more oxygen being released in tissues at a lower partial pressure. ${ }^{23}$ The production of carbon dioxide decreases but the solubility increases. Therefore, in association with hypoventilation, the high level of carbon dioxide causes decreases in $\mathrm{pH}$. Metabolic acidosis develops particularly after discontinuation of bypass because the lactic acid is carried from the periphery to the general circulation. ${ }^{24}$ The heart rate decreases to approximately half the normothermic baseline at $25^{\circ} \mathrm{C} .{ }^{24}$ In the electrocardiogram (ECG), a prolongation of PR interval, widening of the QRS, changes in ST and T wave are observed. Cardiac output and arterial pressure are also decreased to $\sim 33 \%$ of the normothermic conditions. ${ }^{24}$

Therefore in dogs, the major advantage of maintaining hypothermic conditions is the reduction in metabolic needs that allows a reduction of flow from $100 \mathrm{~mL} / \mathrm{kg} / \mathrm{min}$ to $30 \mathrm{~mL} / \mathrm{kg} / \mathrm{min}$ with deep hypothermia. ${ }^{25}$ However, hypothermia can induce several effects on the management of bypass. The metabolic rate and oxygen consumption are decreased with hypothermia, and the release of excitatory neurotransmitters is also reduced. ${ }^{26}$ Compared to normothermic perfusion, hypothermia allows better myocardial protection, lower flows, less blood trauma, and better organ perfusion. Therefore, mild-to-moderate hypothermia $\left(>25^{\circ} \mathrm{C}\right.$ ) is commonly used in human patients undergoing surgery. ${ }^{26}$

Occasionally, deep hypothermic arrest is induced in surgeries involving the aorta and the cerebral vessels and in some complex congenital repairs in pediatric patients. ${ }^{26}$ Hypothermia can be detrimental if used without bypass because of the difficulty in re-warming which is easily and quickly done with bypass. Three approaches to 
hypothermia can be used under CPB: blood-cooling, cold cardioplegic coronary perfusion, and/or surface hypothermia. ${ }^{26}$ Small dogs were maintained for $45 \mathrm{~min}$ utes at $15-18^{\circ} \mathrm{C}$ with a flow of $20 \mathrm{~mL} / \mathrm{kg} / \mathrm{min},{ }^{27}$ and the pump flow reached the lowest flow rate of 29.2 $\mathrm{mL} / \mathrm{kg} / \mathrm{min}$ in a different group of small dogs at $21.4^{\circ} \mathrm{C}$. $^{2}$ In this series, slow cooling and quick re-warming seemed to be the key to successful management. The mean \pm $\mathrm{SD}$ temperature reported during $\mathrm{CPB}$ is $29.5 \pm 4.7^{\circ} \mathrm{C}$. Shibazaki et al looked at the hemodynamic changes under normothermic and hypothermic conditions in dogs and they had a mean temperature of $26.57 \pm 0.65^{\circ} \mathrm{C}$ in the hypothermic group and $36.00 \pm 0.26^{\circ} \mathrm{C}$ in the normothermic group. ${ }^{28}$ The lowest reported temperature was documented by Lew et al with values between 15 and $18^{\circ} \mathrm{C}^{27}$

\section{SMALL PATIENTS}

Small patients present a challenge because of their limited blood volume, risk of hemodilution, and electrolyte disturbances, the small vessels for cannulation, and the need for very small circuits. There is limited experience in operating on small veterinary patients. Under normothermic conditions, the high flow rate may be maintained with difficulty using very small cannulae and tubing. To date, CPB has been successfully performed in cats ${ }^{29}$ and small dogs in experimental settings under deep hypothermic low flow CPB. ${ }^{27} \mathrm{CPB}$ has been used in clinical cases using surface hypothermia (weight $<5.5 \mathrm{~kg}$ ), ${ }^{2}$ and under moderate hypothermia to repair pulmonic stenosis (weight: $4.7 \pm$ $0.7 \mathrm{~kg}) .^{3}$

\section{LIMITED BLOOD VOLUME}

Limited blood volume is a major concern in veterinary patients undergoing cardiac surgery. It is related to patient size, limited availability of blood products and possible blood transfusion reaction even with cross-match. Blood volume in dogs is estimated to be $10 \%$ of body weight. Gibson et al in a study preceding the discovery of CPB by Gibson himself, looked at the total blood volume in dogs between 5 and $30 \mathrm{~kg} .{ }^{30}$ The minimum volume of $84 \mathrm{~mL} / \mathrm{kg}$ and the maximum volume of $97.3 \mathrm{~mL} / \mathrm{kg}$ correlated with the minimum and maximum weight, respectively. Most cardiac conditions with potential for surgical treatment occur in dogs weighing $<15 \mathrm{~kg}$ and more likely between 5 and 10 $\mathrm{kg}$. With this small size, hemodilution becomes a concern when the priming volume approaches the circulating volume. A safe limit of hemodilution during normothermic CPB in dogs with a flow rate of $80 \mathrm{~mL} / \mathrm{kg} / \mathrm{min}$ was found to be higher than $20 \%{ }^{31}$ Both oxygen delivery and whole body oxygen uptake decrease when the hematocrit values are below $18 \% .{ }^{32}$ The formula to estimate the postdilutional
Table 3 Reported Hematocrit

\begin{tabular}{ll}
\hline Hematocrit & \multicolumn{1}{c}{ References } \\
\hline $22 \%$ & Akiyama et al ${ }^{70}$ \\
$20 \%$ & Kanemoto et $\mathrm{ll}^{2}$ \\
$23-30 \%$ & Klement and colleagues $^{33,66}$ \\
$28 \% *$ & Lew et al ${ }^{13}$ \\
$18-20 \%$ & Lew et al ${ }^{27}$ \\
$>25 \%$ & Monnet et al \\
$30 \%$ & Rosenkratz et al \\
$18 \% *$ & Tanaka et al \\
\hline
\end{tabular}

*Indicates post bypass.

hematocrit (Hct), if nonhemic prime is used, is:

$$
\mathrm{CPB} \mathrm{Hct}=\mathrm{Hct}_{\mathrm{b}} \times \mathrm{BV} / \mathrm{TPV}
$$

$\mathrm{Hct}_{\mathrm{b}}$ is the baseline Hct, BV is the patient's blood volume, and the TPV is the total priming volume (priming circuit + dog's volume). Table 3 shows the hematocrit reported in veterinary publications. Hematocrit was significantly lower if compared to baseline values, from $42 \%$ to $29 \%$ in normal dogs undergoing hypothermic $\left(27^{\circ} \mathrm{C}\right) \mathrm{CPB}$ with cardiac arrest. $^{33}$

A feasible, advantageous CPB set up in small patients is obtained by using roller pumps (Fig 6), by minimizing the circuit with the reduction of length and diameter of the tubing, and by using low volume bubble traps and pediatric oxygenators. Centrifugal pumps offer several advantages over roller pumps including decreased trauma to the blood, no possibility of excessive line pressure and tubing disruption, less risk for air emboli, less cavitation, and no tubing wear or spallation caused by rollers on the pump head. ${ }^{21}$ However, roller pumps remain commonly used in human pediatric cardiac surgery due their higher accuracy (compared to centrifugal pumps) in delivering precise volumes at low flow rates. ${ }^{34}$ The low flow limitation of the centrifugal pump is $\sim 800 \mathrm{~mL} / \mathrm{min}$. A roller pump can deliver rates as low as $100 \mathrm{~mL} / \mathrm{min} .{ }^{34}$ For a patient weighing $2 \mathrm{~kg}$ whose calculated flow rate is 400 $\mathrm{mL} / \mathrm{min}$, using a delivery rate of $200 \mathrm{~mL} / \mathrm{kg} / \mathrm{min}$, the use of a centrifugal pump would have unreliable flow rates and possible retrograde flow at low rates. Other advantages of roller pumps are the lower cost, easy to sterilize, and variable stroke volumes for different size patients. ${ }^{34}$ Small dogs can suffer significant hemodilution with a large priming volume in the circuit. Reducing the internal diameter of the tubing and mobilizing the pump heads can dramatically affect the priming volume. Infant oxygenators meet most of the requirements needed to bypass medium and small dogs. Terumo BabyRx (Terumo Cardiovascular Systems Corporation, Ann Arbor, MI), as an example, has a very low priming volume $(43 \mathrm{~mL})$. Its use decreases hemodilution. Larger oxygenators (Terumo Sx10 or RX 15) can provide higher flow (between 2.09 and $5.0 \mathrm{~L} / \mathrm{min}$ ) necessary to bypass larger dogs. (Terumo cardiovascular products. CAPIOX RX Oxygenators 


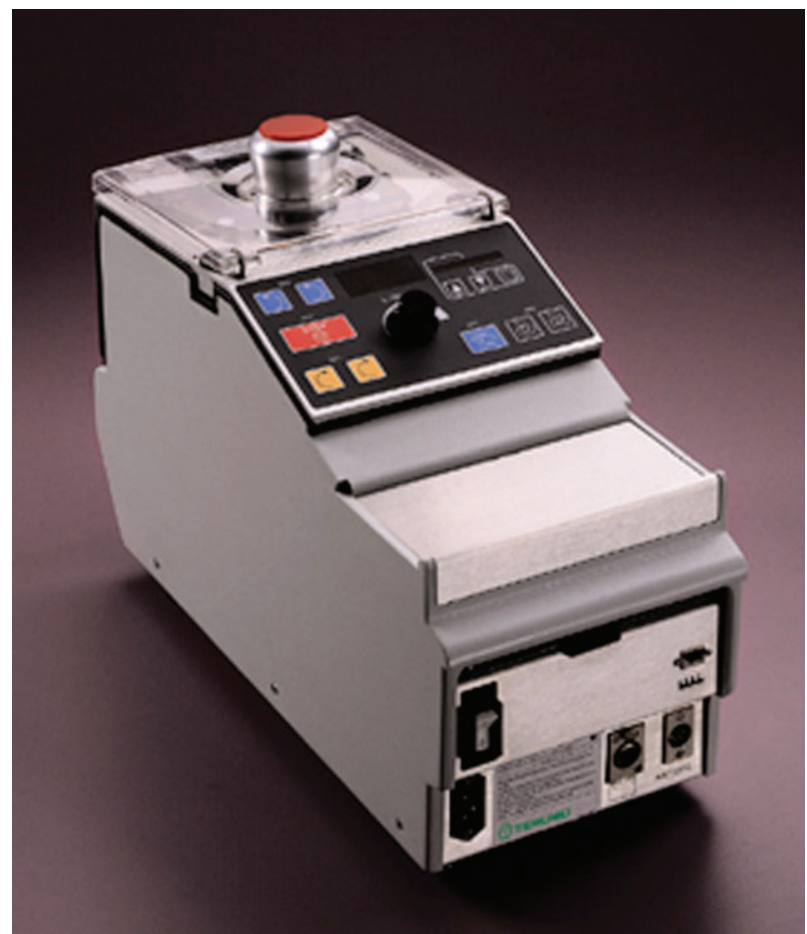

Figure 6 Roller pumps (courtesy of Mike Brigham-Terumo Cardiovascular Systems).

http://www.terumo-cvs.com/images/products/SpecTab_ CAPIOXRX-Oxy_02-09.jpg)

The smallest priming volume of the circuit including the oxygenator reported in veterinary medicine is $225 \mathrm{~mL}$ in toy breeds, ${ }^{2} 260 \mathrm{~mL}$ for small breeds, ${ }^{2}$ and $150 \mathrm{~mL}$ in cats. ${ }^{29}$ Reduction in prime can also be obtained by using vacuumassisted venous drainage which allows use of smaller diameter venous lines, and positioning of the reservoir closer to the field and the patient. ${ }^{35}$

To counteract hemodilution in dogs (and cats), the addition of donor's blood can be contemplated. If blood is needed, the volume of blood added to the patient is determined by the following formula:

$$
\mathrm{V}=\left[\left(\mathrm{Hct}_{\mathrm{d}} \times \mathrm{TPV}\right)-\left(\mathrm{Hct}_{\mathrm{b}} \times \mathrm{BV}\right)\right] / \mathrm{Hct}_{\mathrm{t}}
$$

$\mathrm{V}$ (volume required in the prime), $\mathrm{Hct}_{\mathrm{d}}$ is the desired hematocrit on $\mathrm{CPB}, \mathrm{Hct}_{\mathrm{b}}$ the patient's hematocrit before $\mathrm{CPB}$, $\mathrm{Hct}_{\mathrm{t}}$ hematocrit of donor blood, BV is the patient's blood volume, and the TPV is the total priming volume (priming circuit + dog's volume). ${ }^{27}$

In a veterinary case series, the use of sanguineous priming solution did not result in any side effects but instead helped to attenuate the decline in hematocrit. ${ }^{2}$ Most referral institutions practicing open heart surgery can rely on readily available blood products. Use of autologous transfusions during or post CPB has been advocated as a way to reduce the need for postoperative blood products ${ }^{36}$ and could be a solution for hemodilution in veterinary medicine. However, priming the bypass circuit without using blood solutions is currently recommended because of the decrease in cardiac index, higher pulmonary resistance, and higher levels of inflammatory cytokines seen when sanguineous solutions are implemented. ${ }^{37}$ Moreover, the administration of blood products in the priming solution has been associated in people and dogs with a syndrome of arterial hypotension, portal hypertension and metabolic acidosis. ${ }^{36}$ Reactions to homologous transfusion can occur in dogs and cats. In dogs, there are 7 known blood groups and one newly recognized antigen (DAL) whose clinical significance has not been fully investigated. If proper cross-match and pretransfusion screening procedures are followed, the problem in dogs will most likely occur in patients previously sensitized. ${ }^{38}$ Cats are considered to have 3 blood groups and the incompatibility can be extremely high. Cats have naturally occurring antibodies which are responsible for the high incompatibility, and the potentially life-threatening transfusion reactions even without being previously sensitized. ${ }^{39}$ Therefore, minimizing the use of blood products during or after heart surgery is probably the safest measure.

Different nonblood priming solutions based on 3 different crystalloid solutions $(2.5 \%$ dextrose in electrolyte solution, Normosol R (Hospira, Inc., Lake Park, IL), and Plasma-Lyte 148 (Baxter, Deerfield, IL) were tested in dogs to evaluate the efficacy and side effects, if used in substitution to sanguineous solutions. In this study, no difference was found when these solutions were substituted to blood priming. ${ }^{36}$ Priming solutions contain different electrolytes, buffers (sodium bicarbonate), glucose, heparin, and low concentration of calcium to avoid the iodizing effect of calcium during ischemic arrest. ${ }^{37}$ The veterinary literature suggests that crystalloid priming solutions are used more frequently than their sanguineous counterparts.

\section{BLOOD TRAUMA}

The ideal oxygenator should have a minimal priming volume and should induce minimal blood damage while exchanging oxygen and removing carbon dioxide from the body. ${ }^{40}$ The membrane oxygenator (Fig 7A), resembles in functionality and design a physiologic lung, more than any other oxygenator. However, despite this resemblance, it still has a smaller surface area and limited capacity compared to the lung. The maximum oxygen transfer of the artificial lung is $<25 \%$ the normal lung. ${ }^{40}$ Most veterinary studies used membrane oxygenators in the bypass circuit $(21 / 33$ reports, providing this information). Bubble oxygenators are currently still used in a few centers for procedures requiring short periods of CPB. The simplicity of use and reduced expense are definitely reasons why the bubble oxygenator has not been completely abandoned despite the increased cellular damage. In fact, disc and bubble oxygenators (Fig 7B) are direct contact oxygenators where the bubbles are in direct contact with the blood, increasing the trauma to 


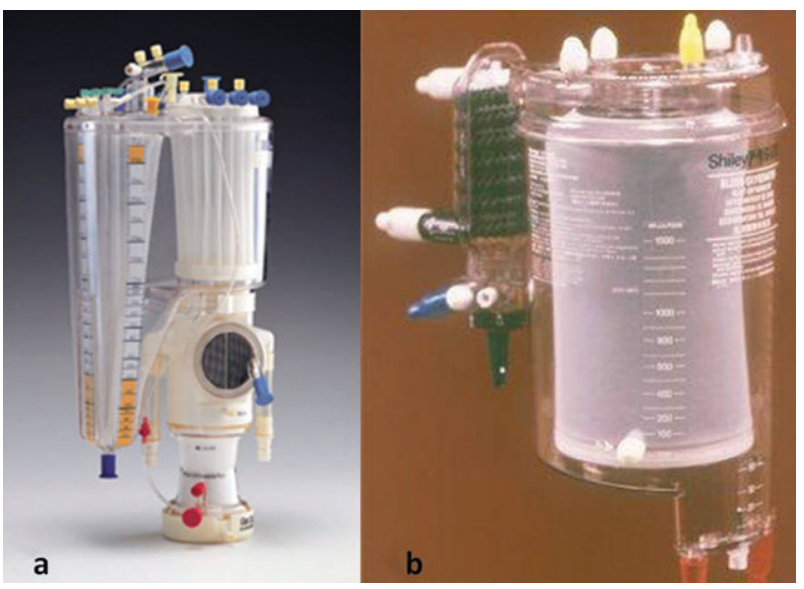

Figure 7 Membrane oxygenator (A) and bubble oxygenator (B; courtesy of Mike Brigham-Terumo Cardiovascular Systems).

the red blood cells. ${ }^{40}$ Bubble oxygenators (Temptrol and Shiley) were found in the older veterinary reports although the most recent publication with their use was $1997 .{ }^{41}$ Disc oxygenators were used only in $2 / 33$ studies. ${ }^{42,43}$

Hemolysis can also be produced by other parts of the circuit and varies with different types of pumps, different flow rates, and different pressure. Some of these effects only occur during the procedure and others persist after discontinuation of bypass. ${ }^{44}$ Several factors determine mechanical damage to the red blood cells during CPB: positive pressure, wall impact forces, blood flowing on nonendothelial surfaces, application of negative pressure if applied, bloodair interface, and shear forces. ${ }^{45-47}$ Shear forces are particularly detrimental on RBC survival, in particular when the forces are applied for long periods. The magnitude varies in the different parts of the circuit: throughout the arterial side, the shear forces are high but short in duration, while on the venous side, the magnitude is lower but the duration is higher. ${ }^{48}$

There is very little experience with centrifugal pump effects in animals because of the paucity of cases in which it has been used and the limitation to experimental settings. ${ }^{49}$ Centrifugal pumps have been shown to produce less hemolysis and platelet activation than roller pumps. However, management of these pumps is more challenging and they are normally preferred for high volume flows and low pressures. ${ }^{34}$ When using roller pumps, the CPB effects on blood cells and coagulation can be divided into different categories: the direct effect of the pump inducing mechanical damage on the blood's components, the activation of the coagulation pathways, the inflammatory response, and the indirect effect induced by the administration of anticoagulants. Therefore, the many advantages of using roller pumps in veterinary medicine are tempered by the major disadvantage of inducing more blood damage compared to the centrifugal pumps.

\section{CARDIAC ARREST AND MYOCARDIAL PROTEC- TION}

Few cases of beating heart surgery are reported in the veterinary literature. ${ }^{4-6,16}$ The major risk of operating with beating heart is the formation of fatal air embolism during the procedure. Procedures on the right side can be safely done without cardiac arrest as long as intracardiac communications are not present. Operations on the left side require arresting the heart by using aortic cross-clamping and administration of a high potassium crystalloid solution, called cardioplegia. The term comes from the Greek and means arrest of the heart. The sole use of potassium in the solution could potentially result in poor myocardial protection. ${ }^{23}$ Therefore, several different solutions are available and can be chosen to reduce the consequences of reperfusion injury. A summary of the most common solutions used in veterinary patients is illustrated in Table 4.

Using cardioplegia solutions adds an additional level of complexity to the procedure and specific strategic plans have to be made during the procedure, depending on the approach and the surgery performed. Cardiac arrest is induced by administrating potassium in a concentration ranging from 10 to $40 \mathrm{mmol} / \mathrm{L}^{23}$ The solutions are described as intracellular (low sodium and calcium concentration) and extracellular (higher concentrations of sodium, calcium, and the addition of magnesium). They can be used in a crystalloid form or in a mixture with a proportion of $4: 1$ crystalloid to sanguineous solution. The theoretical advantages of using sanguineous solutions are the buffering capability, the oxygen carrying capacity, similarity in electrolyte composition, and the presence of free radical scavenging ability in the sanguineous solution. ${ }^{23}$ However, the formulation tends to be more complex and there is lack of evidence to prove physiologic benefits of a sanguineous solution in the animal model. ${ }^{7}$ The most common delivery routes are either antegrade through the aortic root or retrograde into the coronary sinus. Controversy exists in people on the administration of "cold" $\left(\sim 4^{\circ} \mathrm{C}\right)$, "warm" $\left(34-35^{\circ} \mathrm{C}\right)$, or "tepid" (both warm and cold) cardioplegia. ${ }^{23}$ Table 4 shows the reported temperature of the cardioplegia solutions used in the veterinary literature. The solution can also be administrated intermittently or continuously. Although the advantage of one over the other cannot be investigated in veterinary patients for the lack of reported use of continuous administration, it appears that continuous delivery can result in better myocardial performance after bypass in people. ${ }^{40}$

\section{COAGULATION}

Anticoagulation during bypass is normally achieved in people and veterinary surgery with heparin given intravenously. Heparin has been widely used in veterinary medicine in various settings. It is therefore surprising that the literature regarding its use lacks scientific evidence and consensus. 


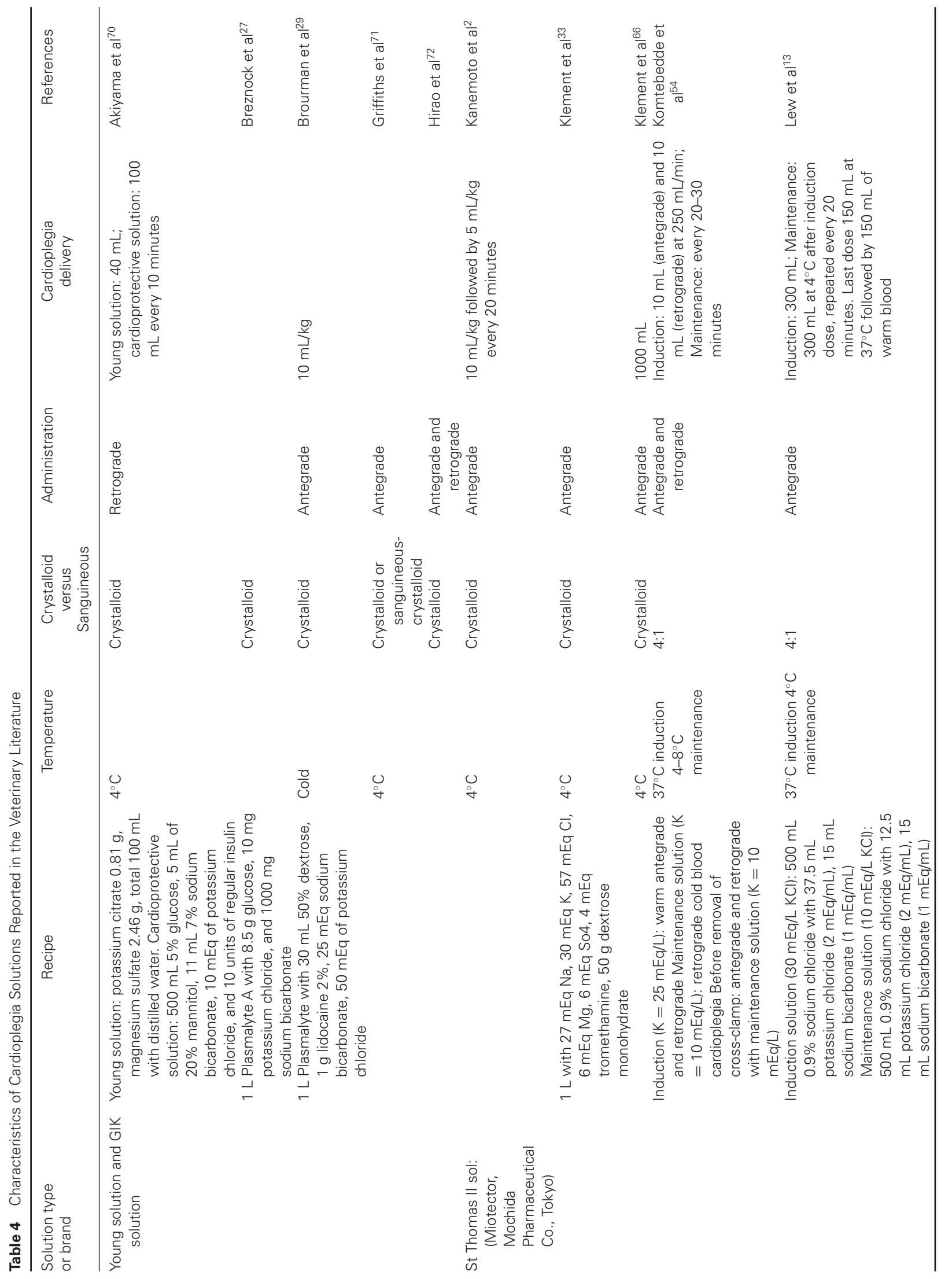




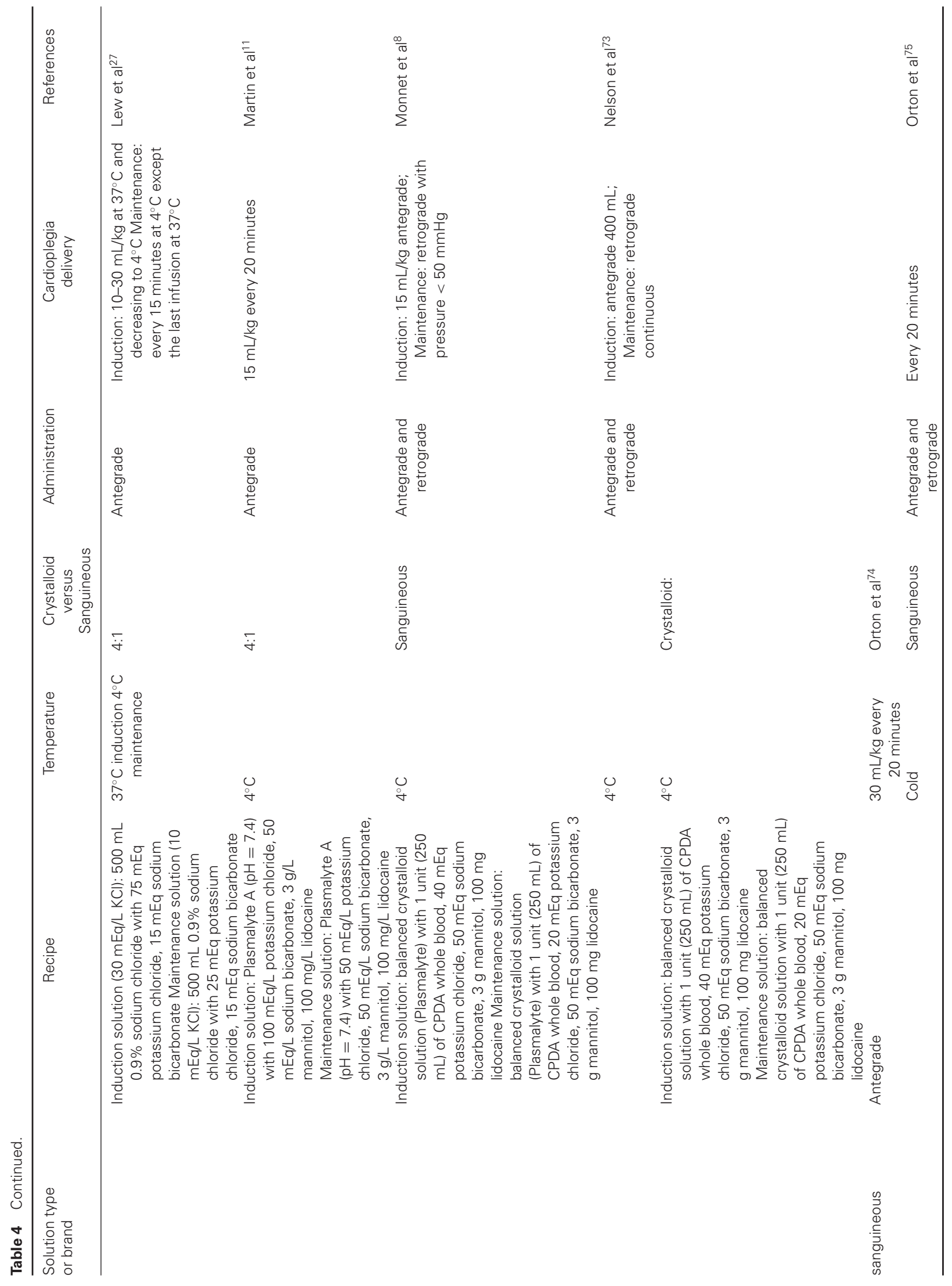




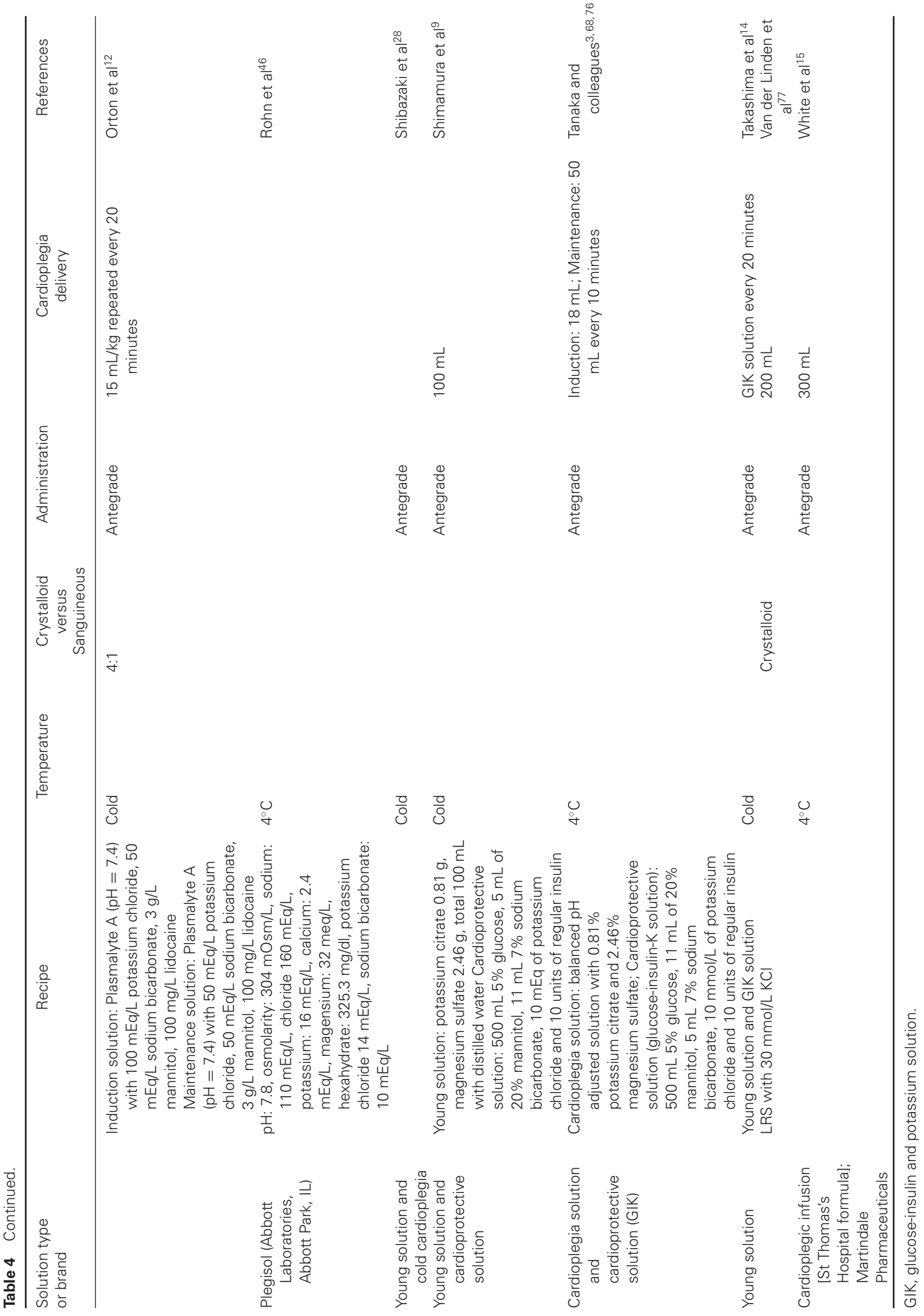


The dose of heparin normally given to people is $300 \mathrm{U} / \mathrm{kg}$ intravenously before cannulation to achieve an activated clotting time $(\mathrm{ACT})$ reading of $>480$ seconds. ${ }^{50}$ Coating the circuit ( $3 \mathrm{U} / \mathrm{mL}$ in the solution) can decrease the dose of intravenous heparin needed. ${ }^{50}$ Throughout the veterinary literature, the doses used are variable and there is no reference to their rationale (Table 5). Also lacking is a reference regarding the best way to monitor coagulation in this setting. When laboratory assessment of coagulation is available, ACT is not commonly a routine screening test in patients with coagulopathy because (activated partial thromboplastin time) aPTT is more sensitive. ACT is used in human medicine because it provides point-of-care monitoring during bypass. However, in children, ACT does not correlate to plasma level of heparin. ${ }^{51}$ Furthermore, ACT can be affected by hemodilution and hypothermia which can make the interpretation of the results more challenging especially in pediatric patients and in small dogs. ${ }^{51}$ The expected range of ACT during $\mathrm{CPB}$ has not been established in veterinary patients and different bedside tests may result in variable accuracy and sensitivity in monitoring heparin response during $\mathrm{CPB}$. When postoperative bleeding occurs, it could be because of an incomplete reversal of heparin or to a different mechanism, including platelets activation, inflammatory pathways, or hemodilution. CPB creates a procoagulable state by causing platelet activation and inflammation leading to platelet dysfunction and depletion, ${ }^{44}$ which is believed to be a major component of postoperative bleeding in human patients. Routine ACT tests cannot distinguish between prolonged blood clotting because of heparin effect or acquired abnormalities of the coagulation system after a loading dose of heparin for bypass. Heparinase ACT testing may assist and be used to ascertain whether or not more protamine needs to be given to adequately reverse the effect of heparin. ${ }^{52}$ In dogs, it was hypothesized that using continuous infusion with dypiridamole could be responsible for decreasing the incidence of postoperative bleeding after heart surgery. ${ }^{32}$ Heparin is normally reversed with protamine. Protamine administration can induce severe side effects (hypotension and pulmonary vasoconstriction) in up to $70 \%$ of dogs previously treated with heparin and receiving an infusion of $2.5 \mathrm{mg} / \mathrm{kg} .{ }^{53}$ The adverse reactions are minimized in dogs when protamine is administered via cephalic vein slowly $(5 \mathrm{mg} / \mathrm{min}){ }^{53}$ The effect of protamine is unknown in cats because of the limited studies available. Brourman et al reported high ACT reading after administration of protamine. They indicated this finding as the possible result of incomplete reversal in cats or the result of protamine-derived anticoagulant effect. $^{29}$

\section{PHYSIOLOGIC AND PATHOLOGIC FINDINGS DUR- ING AND AFTER BYPASS}

The complete list of the most common complications associated with CPB is summarized in Tables 6 and 7. Duration of bypass and aortic cross-clamping are important factors to consider in the overall incidence of complications. From the information reported, the mean CPB time is $92.4 \pm$ 51.5 minutes and the average cross-clamping time under normothermic and hypothermic conditions is $54 \pm 29.1$ minutes. Minimizing both periods is in the best interest of the patient. Considering the extensive use of the literature in any review manuscript, the true incidence of complications and the estimate of their impact on the overall outcome cannot be precisely determined.

\section{Cardiovascular and Hemodynamic Changes}

During CPB, perfusion pressures are lower than arterial pressures under anesthesia. The minimal perfusion pressure necessary to maintain capillary patency is also a function of the applied conditions. Hypotension can be associated with administration of protamine, ${ }^{54}$ but it is commonly seen after discontinuation of bypass in dogs. ${ }^{27,54}$ Lew et al observed biphasic hypotensive episodes occurring in the immediate postoperative period and after 15 hours. ${ }^{27}$ Compared to hypothermic CPB, mean arterial pressure is lower upon discontinuation of the bypass in dogs under normothermic conditions. $^{28}$ Diastolic blood pressure after CPB has been noted to be reduced compared to baseline values and to remain relatively low in dogs for the first few hours after conclusion of bypass. ${ }^{33} \mathrm{CPB}$ can also induce acute myocardial edema which is responsible for decreasing left ventricular systolic function in dogs. ${ }^{55}$ Positive inotropic drugs are commonly used in people during the postoperative phase in order to provide necessary cardiovascular support. ${ }^{56}$ Central venous pressures are significantly lower in hypothermic conditions during bypass. ${ }^{28}$

\section{Hematologic and Biochemical Changes}

Electrolyte changes are commonly observed during and after CPB in domestic animals. Hematocrit is decreased after CPB because of hemodilution, hemolysis, coagulopathy, and blood loss in the postoperative period. ${ }^{27,29,33,36,45,57-59}$ Compared to normothermic conditions, hypothermia in dogs does not seem to affect hematocrit, hemoglobin, total protein concentrations, and plasma osmotic pressure, but it produces a decrease in sodium, chloride, and white blood cell count during bypass, while the aspartate aminotransferase (AST) and creatine kinase (CK) increase after bypass. ${ }^{28}$ Embolic diseases are often observed in people. ${ }^{59}$ Hypokalemia is commonly observed during and after CPB, and can be easily corrected with intravenous administration of potassium. ${ }^{27-29,59}$ The use of high potassium cardioplegia solutions has decreased the incidence of hypokalemia in human patients and it has been responsible occasionally for intraoperative hyperkalemia. ${ }^{23}$ Hyperkalemia has been documented in dogs under CPB and favorably treated with insulin and dextrose. ${ }^{27}$ Other electrolytes closely monitored during CPB in people are calcium and magnesium because 
Table 5 Heparin and Protamine Doses Used with the Activated Clotting Time (ACT) Values Obtained after Heparin Administration

\begin{tabular}{|c|c|c|c|}
\hline Heparin & ACT (seconds) & Protamine & References \\
\hline $0.35-0.45 \mathrm{mg} / \mathrm{kg}$ & & & Pullen et $a^{51}$ \\
\hline $1.5 \mathrm{mg} / \mathrm{kg}$ & $240-360$ seconds $^{7}$ & & Breznock and colleagues ${ }^{7,42}$ \\
\hline $10,000 \mathrm{U}$ & & $10.5 \mathrm{mg}^{10}$ & Breznock and colleagues ${ }^{10,73}$ \\
\hline $100 \mathrm{U} / \mathrm{kg}$ & $\begin{array}{l}>480 \text { seconds }^{70} \\
>400 \text { seconds }^{3,9,76}\end{array}$ & & Tanaka and colleagues $3,9,68,70,72,76,78$ \\
\hline $100 \mathrm{U} / \mathrm{kg}+50 \mathrm{U} / \mathrm{kg} / \mathrm{h}$ & NA & $0.75 \mathrm{mg} / \mathrm{kg}$ & Akkerman et al ${ }^{78}$ \\
\hline $100 \mathrm{U} / \mathrm{kg}+75 \mathrm{U} / \mathrm{kg} / \mathrm{h}$ & NA & & Rohn et al $\left.\right|^{55}$ \\
\hline $2 \mathrm{mg} / \mathrm{kg}$ & NA & $5 \mathrm{mg} / \mathrm{kg}$ & Shiang et $a l^{36}$ \\
\hline $2.5 \mathrm{mg} / \mathrm{kg}$ & $\begin{array}{l}>600(5-6 \text { times from pre bypass })^{4} \\
864^{5}\end{array}$ & 1.4 dose of heparin ${ }^{4,5}$ & Behr and colleagues ${ }^{4,5}$ \\
\hline $200 \mathrm{U} / \mathrm{kg}$ & $>400$ seconds & & Soda et $\mathrm{al}^{6}$ \\
\hline $250 \mathrm{U} / \mathrm{kg}$ & NA & $\begin{array}{l}10 \mathrm{mg} / 1000 \cup \text { heparin } \\
1 \mathrm{mg} / 10 \cup \text { heparin }\end{array}$ & Boggs et $a^{58}$ \\
\hline $3 \mathrm{mg} / \mathrm{kg}$ & $\begin{array}{l}>480 \text { seconds }^{20,57,61} \\
>400 \text { seconds }^{45}\end{array}$ & $\begin{array}{l}1 \mathrm{mg} / \mathrm{mg} \text { heparin } 20,57 \\
0.8-1.2 \mathrm{mg} / \mathrm{mg} \text { heparin }^{61,67}\end{array}$ & Martin and colleagues ${ }^{11,12,33,43,54,66}$ \\
\hline $300 \mathrm{U} / \mathrm{kg}$ & $\begin{array}{l}>450 \text { seconds }^{78} \\
>480 \text { seconds }^{12,50,64,70}\end{array}$ & $\begin{array}{l}1.3-1.5 \mathrm{mg} / 100 \mathrm{U} \text { heparin, }{ }^{12,64} \\
0.75 \mathrm{mg} / \mathrm{U} \text { heparin, } \\
1,75 \\
1 \mathrm{mg} / 100 \cup \text { heparin, }^{15} \\
1 \mathrm{mg} / 1000 \mathrm{U} \text { heparin }^{80}\end{array}$ & Monnet and colleagues $8,13,15,27,41,75,80$ \\
\hline $350 \mathrm{U} / \mathrm{kg}$ & & $42 \mathrm{mg}$ & Eyster et $a^{16}$ \\
\hline $400 \mathrm{U} / \mathrm{kg}$ & $>480$ seconds & $2 \mathrm{mg} / \mathrm{kg}^{2}$ and $4 \mathrm{mg} / \mathrm{kg}^{29}$ & Kanemoto and colleagues 2,29 \\
\hline $4 \mathrm{mg} / \mathrm{kg}+2 \mathrm{mg} / \mathrm{kg}$ after 30 minutes & NA & $12 \mathrm{mg} / \mathrm{kg}$ slow infusion & Rosenkratz et al ${ }^{57}$ \\
\hline $5 \mathrm{mg} / \mathrm{kg}+1-2 \mathrm{mg} / \mathrm{kg}$ maintenance & $>450$ seconds & & Van de Linden et al ${ }^{77}$ \\
\hline
\end{tabular}

Table 6 Complications Observed During Bypass

\begin{tabular}{|c|c|c|c|c|}
\hline Complications & Timing & Possible mechanism & Treatment & References \\
\hline \multicolumn{5}{|l|}{ Arrhythmia } \\
\hline Ventricular fibrillation & & Myocardial reperfusion & Electroconversion & Monnet and colleagues ${ }^{8,27}$ \\
\hline \multicolumn{5}{|c|}{ Cardiovascular and hemodynamic } \\
\hline Hypotension & After onset CPB & $\begin{array}{l}\text { Decrease in viscosity } \\
\text { because of hemodilution, } \\
\text { dilution of } \\
\text { catecolamines, } \\
\text { decreased blood volume }\end{array}$ & & Shiang and colleagues 36,54 \\
\hline Hypertension & & & $\begin{array}{l}\text { Nitroprusside and } \\
\text { isofluorane }\end{array}$ & \\
\hline \multicolumn{5}{|l|}{ Hematologic and biochemical } \\
\hline $\begin{array}{l}\text { Decrease AST and } \\
\text { Alanine transaminase }\end{array}$ & After bypass initiation & & & Shibazaki et al ${ }^{28}$ \\
\hline Hyponatremia & & & & Shibazaki et al ${ }^{28}$ \\
\hline Hypokalemia & & & & Shibazaki et al ${ }^{28}$ \\
\hline Hyperkalemia & After cardioplegia & $\begin{array}{l}\text { Administration of high } \\
\text { potassium cardioplegia } \\
\text { solution, acidosis, } \\
\text { decrease renal filtration }\end{array}$ & Insulin/glucose & Lew et $\mathrm{al}^{27}$ \\
\hline Hypochloremia & & & & Shibazaki et al ${ }^{28}$ \\
\hline Neutropenia & & $\begin{array}{l}\text { Contact with foreign } \\
\text { surfaces, insufficient } \\
\text { hemodilution, } \\
\text { intrapulmonary storage, } \\
\text { release of chemical } \\
\text { mediators }\end{array}$ & & Shibazaki et al ${ }^{28}$ \\
\hline \multicolumn{5}{|l|}{ Others } \\
\hline $\begin{array}{l}\text { Hemorrhage from aortic } \\
\text { cannulation }\end{array}$ & & Tearing of aorta & $\begin{array}{l}\text { Surgical repair and blood } \\
\text { transfusion }\end{array}$ & Lew et $\mathrm{al}^{27}$ \\
\hline
\end{tabular}

they are known to decline upon initiation of $\mathrm{CPB}^{60} \mathrm{Cal}-$ cium may need to be administered upon discontinuation of CPB. Hypomagnesemia can predispose to cardiac arrhythmia, which can be prevented by using supplemental magnesium.

\section{Respiratory Function}

In dogs, $\mathrm{CPB}$ can induce an increase in the postoperative $\mathrm{PCO}_{2}$ and respiratory acidosis which can persist for hours after extubation and can be corrected with 


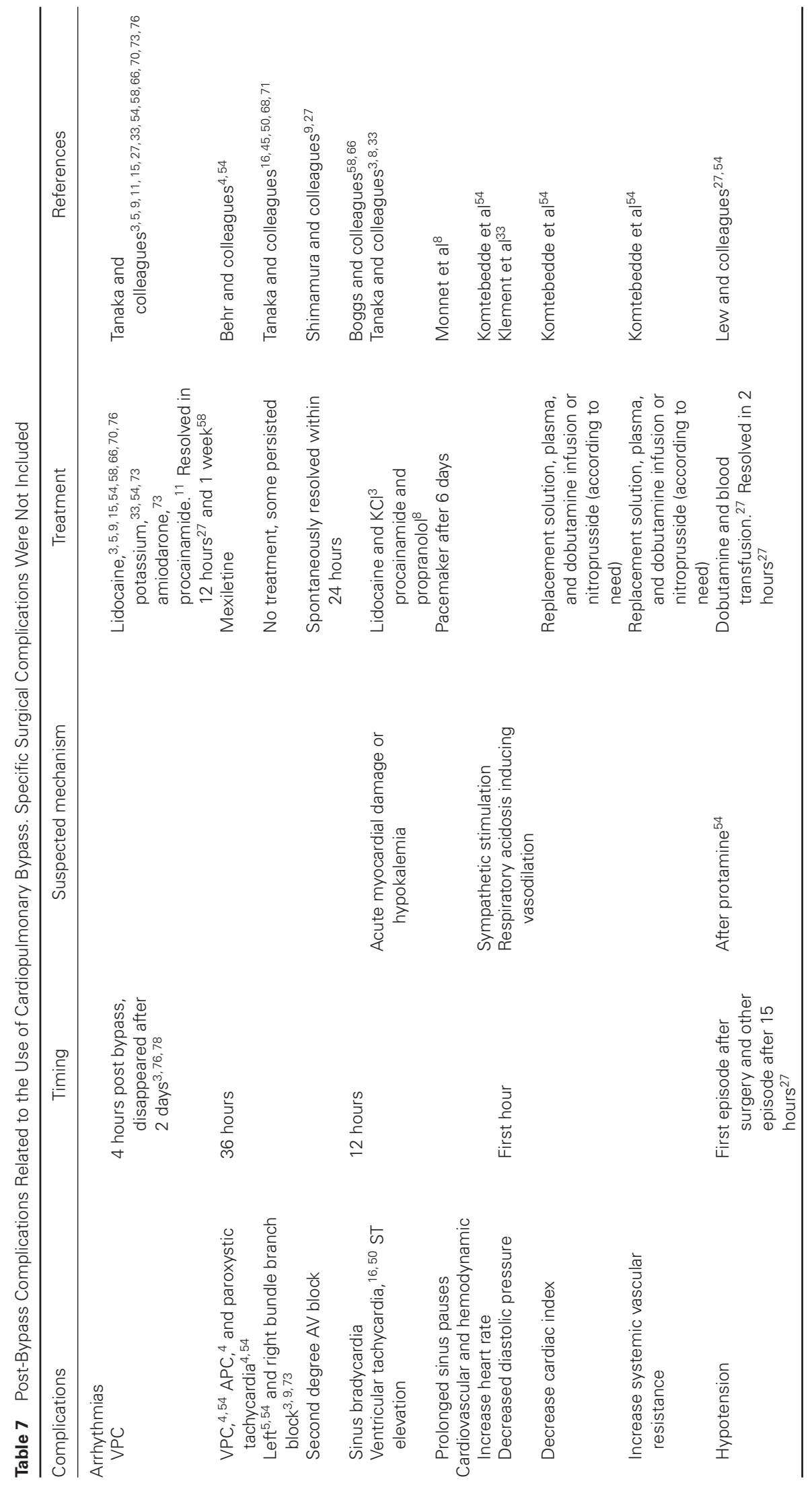




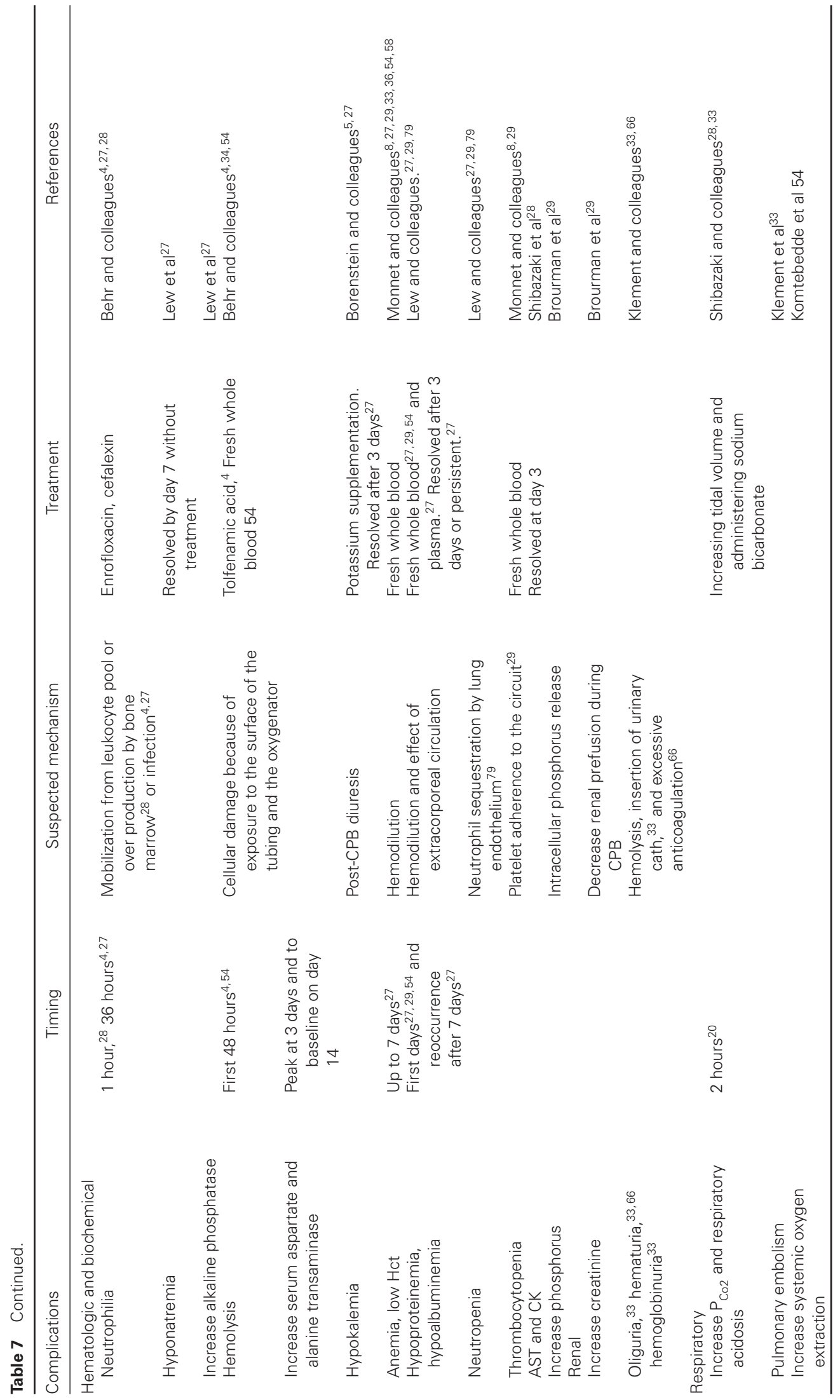




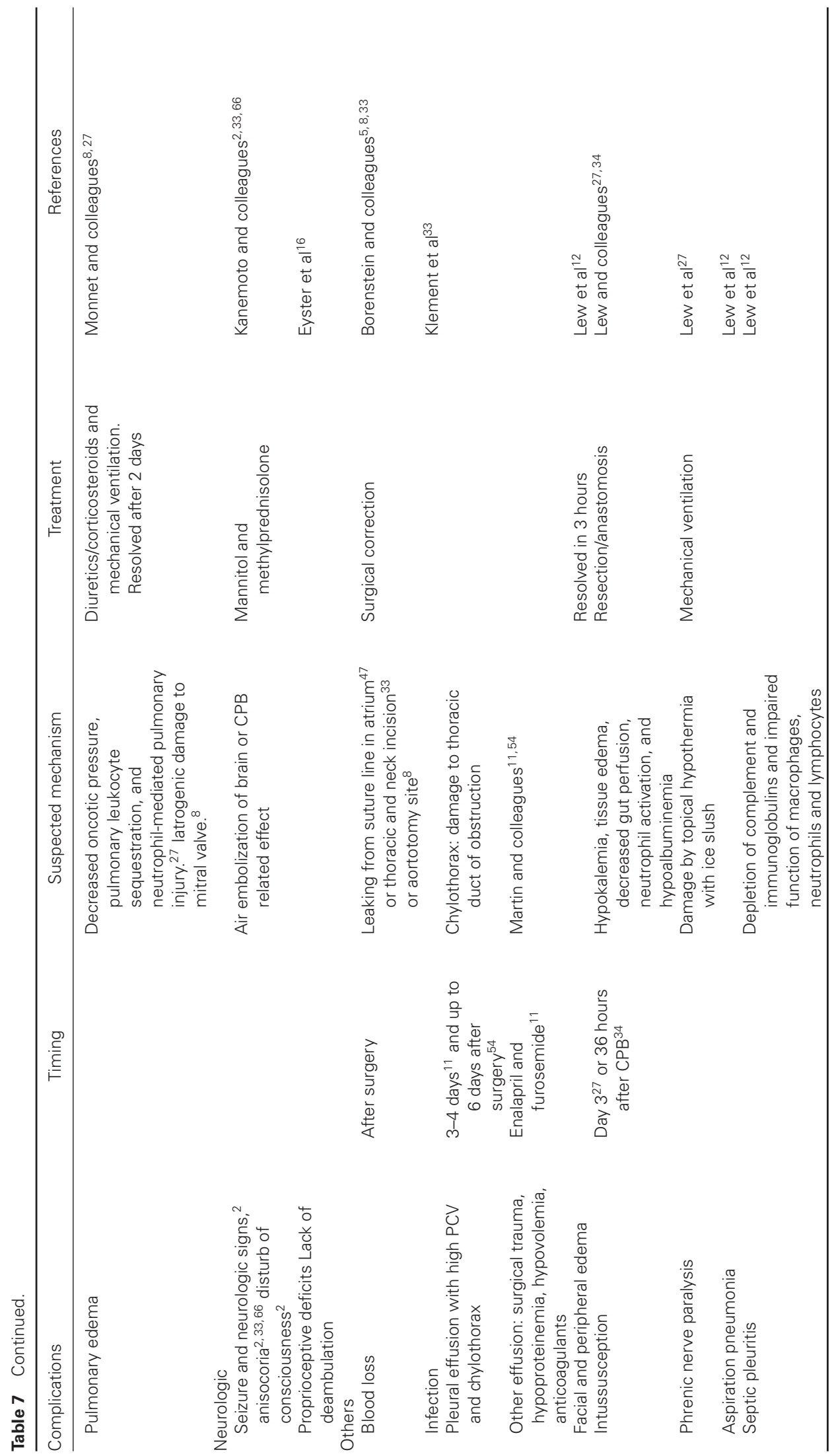


bicarbonate and by increasing the tidal volume. ${ }^{32}$ In patients undergoing hypothermic CPB $\left(24-26^{\circ} \mathrm{C}\right), \mathrm{PO}_{2}$ and $\mathrm{PCO}_{2}$ are higher during and after bypass, respectively, when compared to the normothermic group. ${ }^{28}$ Respiratory acidosis is often observed during and after bypass, hypothermia in dogs seems to induce more pronounced acidosis particularly upon discontinuation of bypass. ${ }^{28}$ Respiratory function can be severely affected if the phrenic nerves get damaged during surface cooling using ice slush. ${ }^{27}$

Controversial data exist regarding ventilation during CPB. The incidence of lung failure after bypass is low in people $(1.7 \%)$ but the mortality is high. ${ }^{62}$ Traditionally, mechanical ventilation is discontinued during CPB. However, low tidal volume ventilation during bypass may decrease lung injury by lowering reperfusion injury and inflammatory response. ${ }^{61,62}$ Unfortunately, there is currently no strong evidence that ventilation during bypass can result in reduction of respiratory complications in people. ${ }^{63}$ Continuous positive airway pressure during CPB has also been postulated to reduce lung injuries. ${ }^{62}$

\section{Other Complications}

Several other complications directly or indirectly associated with CPB have been reported in dogs and cats (Table 7). Neurologic complications (cerebral injury and embolism) seem to be very common in human patients ${ }^{64,65}$ but they are rarely reported in the veterinary literature. ${ }^{2,16,33,66}$ Various renal changes after bypass with hematuria and hemoglobinuria were reported and can be expected because of the hemolysis and the use of anticoagulants. Acute renal failure is a devastating sequela of CPB in people occurring in $\sim 5 \%$ of patients. ${ }^{67}$ None of the cases described in the veterinary literature had renal failure, although oliguria and increased creatinine have been reported. ${ }^{29,33,66}$ Oliguria, severe hypotension, poor perfusion, increased creatinine, and cross-clamp time should be closely monitored to prevent acute renal failure after bypass.

Among other findings, it is relevant to note the rare occurrence of intussusception in both adults and puppies 36 hours after bypass. ${ }^{27,57}$ Possible causes are to be found in hypokalemia, tissue edema, decreased gut perfusion, neutrophil activation, and hypoalbuminemia. ${ }^{27}$

\section{CONCLUSION}

In conclusion, $\mathrm{CPB}$ in domestic species offers a variety of challenges and innovative approaches to the wellestablished practice of perfusion. Some of the features observed in bypassing dogs and cats are very unique to these species, but others are common to other species including people. Further investigation of bypass in dogs and cats can help to advance the knowledge of bypass techniques and prevention of possible complications. Evaluation of precise heparin calculation and reversal is an area of possible research.

\section{REFERENCES}

1. Uechi M, Kayoko H, Mizukoshi T, et al: Surgical closure of the atrial septal defects using cardiopulmonary bypass in a cat. Vet Surg 2011;40:413-417

2. Kanemoto I, Taguchi D, Yokoyama S, et al: Open Heart surgery with deep hypothermia and cardiopulmonary bypass in small and toy dogs. Vet Surg 2010;39:674-679

3. Tanaka R, Shimizu M, Hoshi K, et al: Efficacy of open patch-grafting under cardiopulmonary bypass for pulmonic stenosis in small dogs. Aust Vet J 2009;87:88-93

4. Behr L, Chetboul V, Sampedrano CC, et al: Beating heart mitral valve replacement with a bovine pericardial bioprosthesis for treatment of mitral valve dysplasia in a Bull Terrier. Vet Surg 2007;36:190-198

5. Borenstein N, Daniel P, Behr L, et al: Successful surgical treatment of mitral valve stenosis in a dog. Vet Surg 2004;33:138-145

6. Soda A, Tanaka R, Saida Y, et al: Successful surgical correction of supravalvular pulmonary stenosis under beating heart using a cardiopulmonary bypass system in a dog. J Vet Med Sci 2009;71:203-206

7. Breznock EM: Tricuspid and mitral valvular disease: valve replacement. Semin Vet Med Surg (Small Anim) 1994;9:234-239

8. Monnet E, Orton EC, Gaynor JS, et al. Open resection for subvalvular aortic stenosis in dogs. J Am Vet Med Assoc 1996;209:1255-1261

9. Shimamura S, Kutsuna H, Shimizu M, et al: Comparison of right atrium incision and right ventricular outflow incision for surgical repair of membranous ventricular septal defect using cardiopulmonary bypass in dogs. Vet Surg 2006;35:382-387

10. Breznock EM, Hilwig RW, Vasko JS, et al: Surgical correction of an interventricular septal defect in the dog. $J$ Am Vet Med Assoc 1970;157:1343-1353

11. Martin JM, Orton EC, Boon JA, et al: Surgical correction of double-chambered right ventricle in dogs. J Am Vet Med Assoc 2002;220:770-774

12. Orton EC, Mama K, Hellyer P, et al: Open surgical repair of Tetralogy of Fallot in dogs. $\mathrm{J}$ Am Vet Med Assoc 2001;219:1089-1093

13. Lew LJ, Fowler JD, Mckay R, et al: Open-heart correction of Tetralogy of Fallot in an acyanotic dog. J Am Vet Med Assoc 1998;213:652-657

14. Takashima K, Soda A, Tanaka R, et al: Short-term performance of mitral valve replacement with porcine bioprosthetic valves in dogs. J Vet Med Sci 2007;69:793-798

15. White RN, Stepien RL, Hammond RA, et al: Mitral valve replacement for the treatment of congenital mitral dysplasia in a bull terrier. J Small Anim Pract 1995;36:407-410

16. Eyster GE, Weber W, Chi S, et al: Mitral valve prosthesis for correction of mitral regurgitation in a dog. J Am Vet Med Assoc 1976;168:1115-1158

17. Barone R: Anatomia comparata dei mammiferi domestici, Vol. 5. Bologna, Italia, Edagricole, 1993

18. Wilcox BR, Cook AC, Anderson RH: Surgical anatomy of the heart (ed 3). NY, Cambridge University Press, 2004 
19. Hessel EA : Circuitry and cannulation techniques, in Gravlee GP, Davis RF, Stammers AH, et al (eds): Cardiopulmonary bypass. Principles and practice (ed 3). Philadelphia, PA, Lippincott Williams \& Wilkins, 2008, pp 63-113

20. Orsi M, Stefanini MA, Crocci AJ, et al: Some segmental features on the structure of the aortic wall of the dog. Anat Histol Embryol 2004;33:131-134

21. Wolinsky H, Glagov S: Lamellar unit of aortic medial structure and function in mammals. Circ Res 1967;20:99-111

22. Bigelow WG, Lindsay Wk, Greenswood WF: Hypothermia. Its possible role in cardiac surgery: an investigation of factors governing survival in dogs at low body temperature. Ann Surg 1950;132:849-866

23. Slater MS, Komanapalli CB, Song H: Myocardial protection, in Gravlee GP, Davis RF, Stammers AH, et al (eds): Cardiopulmonary bypass. Principles and practice (ed 3). Philadelphia, PA, Lippincott Williams \& Wilkins, 2008, pp 172-189

24. Weirich WE, Smith CR, Icropera FP, et al: Hypothermia for cardiac arrest surgery in the dog. J Am Anim Hosp Assoc 1973;9:540-547

25. Miyamoto K, Kawashima Y, Matsuda H, et al: Optimal perfusion flow rate for brain during deep hypothermic cardiopulmonary bypass at $20^{\circ} \mathrm{C}$, an experimental study. $J$ Thorac Cardiovasc Surg 1986;92:1065-1070

26. Davies LK: Temperature management in cardiac surgery, in Gravlee GP, Davis RF, Stammers AH, et al (eds): Cardiopulmonary bypass. Principles and practice (ed 3). Philadelphia, PA, Lippincott Williams \& Wilkins, 2008, pp 155-171

27. Lew LJ, Fowler JD, Egger CM, et al: Deep hypothermic low flow cardiopulmonary bypass in small dogs. Vet Surg 1997;26:281-289

28. Shibazaki A, Matsumoto H, Shiroshita Y, et al: A comparative study between hypothermic and normothermic cardiopulmonary bypass in open heart surgery in dogs - effects on systemic hemodynamics. J Vet Med Sci 1999;61:331-336

29. Brourman JD, Schertel ER, Holt DW, et al: Cardiopulmonary bypass in the cat. Vet Surg 2002;31:412-417

30. Gibson JG, Keeley JL, Pijoan M: The blood volume of normal dogs. Am J Physiol 1938;121:800-806

31. Kawashima Y, Yamamoto Z, Manabe H: Safe limits of hemodilution in cardiopulmonary bypass. Surgery 1974;76:391-397

32. Liam B-L, Plochl W, Cook DJ, et al: Hemodilution and whole body oxygen balance during normothermic cardiopulmonary bypass in dogs. $J$ Thorac Cardiovasc Surg 1998;115:1203-1208

33. Klement $\mathrm{P}$, del Nido PJ, Mickleborough L, et al: Technique and postoperative management for successful cardiopulmonary bypass and open-heart surgery in dogs. $J$ Am Vet Med Assoc 1987;190:869-874

34. De Somer FMJJ, Van Nooten G: Blood pumps in cardiopulmonary bypass, in Gravlee GP, Davis RF, Stammers AH, et al (eds): Cardiopulmonary bypass. Principles and practice (ed 3). Philadelphia, PA, Lippincott Williams \& Wilkins, 2008, pp 35-46
35. Giacomuzzi C, Mejiak B, and Shen I: Pediatric cardiopulmonary bypass overview: state of the art and future, in Gravlee GP, Davis RF, Stammers AH, et al (eds): Cardiopulmonary bypass. Principles and practice (ed 3). Philadelphia, PA, Lippincott Williams and Wilkins, 2008, pp 685-699

36. Shiang HH, Chen VL, Mindich BP, et al: Use of nonblood priming for open-heart surgery in dogs. Am J Vet Res 1982;43:1830-1832

37. Cooper JR, Giesecke NM: Hemodilution and priming solution, in Gravlee GP, Davis RF, Stammers AH, et al (eds): Cardiopulmonary bypass. Principles and practice (ed 3). Philadelphia, PA, Lippincott Williams \& Wilkins, 2008, pp 411-422

38. Tocci LJ, Ewing PJ: Increasing patient safety in veterinary transfusion medicine: an overview of pretransfusion testing. JVECC 2009;19:66-73

39. Griot-Wenk ME, Giger U: Feline transfusion medicine. Blood types and their clinical importance. Vet Clin North Am Small Anim Pract 1995;25:1305-1322

40. Stammers AH, Trowbridge CC: Principles of oxygenator function: gas exchange, heat transfer, and operation, in Gravlee GP, Davis RF, Stammers AH, et al (eds): Cardiopulmonary bypass. Principles and practice (ed 3). Philadelphia, PA, Lippincott Williams \& Wilkins, 2008, pp 47-62

41. Cook DJ, Orszulak TA, Daly RC, et al: Minimum hematocrit for normothermic cardiopulmonary bypass in dogs. Circulation 1997;96 (Suppl. 9):II-200-II-204

42. Giannelli S, Mahaja DR, Navarre JR, et al: Studies of blood volume changes during cardiopulmnary bypass in dogs. Annals Surg 1960;152:190-196

43. Longnecker D, Abel FL: Peripheral vascular response to simulated hemorrhagic shock during cardiopulmonary bypass in dogs. Circ Res 1969;25:107-117

44. Rinder CS: Hematologic effects and coagulopathy, in Gravlee GP, Davis RF, Stammers AH, et al (eds): Cardiopulmonary bypass. Principles and practice (ed 3). Philadelphia, PA, Lippincott Williams \& Wilkins, 2008, pp 439-458

45. Valeri R, McGregor H, Ragno G, et al: Effects of centrifugal and roller pumps on survival of autologous red cells in cardiopulmonary bypass surgery. Perfusion 2006;21:291-296

46. Mulholland JW, Massay W, Shelton JC: Investigation and quantification of the blood trauma caused by the combined dynamic forces experienced during cardiopulmonary bypass. Perfusion 2000;15:485-494

47. Wright G. Haemolysis during cardiopulmonary bypass: update. Perfusion 2001;16:345-351

48. Vercaemster L. Hemolysis in cardiac surgery patients undergoing cardiopulmonary bypass: a review in search of a treatment algorithm. $J$ ExtraCorporeal Technol 2008;40:257-267

49. Kim TS, Sun K, Lee KB, et al: Application of a pressure-relieving air compliance chamber in a single-pulsatile extracorporeal life support system: an experimental study. Artif Organs 2004;28:1106-1109

50. Shore-Lesserson L, Gravlee GP: Anticoagulation for cardiopulmonary bypass, in Gravlee GP, Davis RF, 
Stammers AH, et al (eds): Cardiopulmonary bypass. Principles and practice (ed 3). Philadelphia, PA, Lippincott Williams \& Wilkins, 2008, pp 472-501

51. Owings JT, Pollock ME, Gosselin RC, et al: Anticoagulation of children undergoing cardiopulmonary bypass is overestimated by current monitoring techniques. Arch Surg 2000;135:1042-1047

52. DiNardo JA, Zvara DA: anesthesia for cardiac surgery (ed 3). Malden, MA, Blackwell Publishing, 2008

53. Morgan MR, Monnet E, Gaynor JS: The effect of differing rates and injection sites on the amount of protamine delivered before detection of hemodynamic alterations in dogs. Vet Surg 2000;29:442-448

54. Komtebedde J, Ilkiw J, Follette DM, et al: Resection of subvalvular aortic stenosis. Surgical and perioperative management in seven dogs. Vet Surg 1993;22:419-430

55. Rohn DA, Davis KL, Mehlhorn U, et al: Myocardial edema and compromised left ventricular function attributable to dirofilariosis and cardiopulmonary bypass in dogs. Am J Vet Res 1995;56:221-226

56. Royster RL, Thomas SJ: Termination of cardiopulmonary bypass, in Gravlee GP, Davis RF, Stammers AH, et al (eds): Cardiopulmonary bypass. Principles and practice (ed 3). Philadelphia, PA, Lippincott Williams \& Wilkins, 2008, pp 614-631

57. Rosenkrantz JG, Macmahon R, Frost WW, et al: Extracorporeal circulation in puppies. Arch Surg. 1965;91:513-515

58. Boggs LS, Dewan SJ, Ballard SE: Mitral valve reconstruction in a toy-breed dog. J Am Vet Med Assoc 1996;209:1872-1876

59. Walker SG, Stump DA: Embolic events, in Gravlee GP, Davis RF, Stammers AH, et al (eds): Cardiopulmonary bypass. Principles and practice (ed 3). Philadelphia, PA, Lippincott Williams \& Wilkins, 2008, pp 261-281

60. Walker SG, Butterworth JF: Endocrine, metabolic, and electrolyte response, in Gravlee GP, Davis RF, Stammers $\mathrm{AH}$, et al (eds): Cardiopulmonary bypass. Principles and practice (ed 3). Philadelphia, PA, Lippincott Williams \& Wilkins, 2008, pp 282-310

61. Gagnon J: Clinical relevance of ventilation during cardiopulmonary bypass in the prevention of postoperative lung dysfunction. Perfusion 2010;25:205-210

62. John LCH, Ervine IM: A study assessing the potential benefit of continued ventilation during cardiopulmonary bypass. Interactive Cardiovasc Thorac Surg 2008;7:14-17

63. Sasson L, Sherman A, Ezri T, et al: Mode of ventilation during cardiopulmonary bypass does not affect immediate postbypass oxygenation in pediatric cardiac patients. $J$ Clin Anesth 2007;19:429-433

64. Cook DJ: Neurologic effects of cardiopulmonary bypass, in Gravlee GP, Davis RF, Stammers AH, et al (eds): Cardiopulmonary bypass. Principles and practice (ed 3). Philadelphia, PA, Lippincott Williams \& Wilkins, 2008, pp 376-409

65. Carrascal Y, Guerrero AL: Neurological damage related to cardiac surgery: pathophysiology, diagnostic tools and prevention strategies. Using actual knowledge for planning the future. Neurologist 2010;16:152-164

66. Klement P, Feindel CM, Scully HE, et al: Mitral valve replacement in dogs. Surgical technique and postoperative management. Vet Surg 1987;16:231-237

67. Elahi M, Asopa S, Pflueger A, et al: Acute kidney injury following cardiac surgery: impact of early versus late haemofiltration on morbidity and mortality. Eur $J$ Cardiothorac Surg 2009;35:854-863

68. Shimizu M, Tanaka R, Hoshi K, et al: Surgical correction of ventricular septal defect with aortic regurgitation in a dog. Aust Vet J 2006;84:117-121

69. Pullen CM, Gourley IM, Rhode EA : Cardiopulmonary bypass techniques in dogs: comparative study of donor circulation and babble oxygenation. J Am Vet Med Assoc $1973 ; 163: 58-63$

70. Akiyama M, Tanaka R, Maruo K, et al: Surgical correction of a partial atrioventricular septal defect with a ventricular septal defect in a dog. J Am Anim Hosp Assoc 2005;41:137-143

71. Griffiths LG, Orton EC, Boon JA: Evaluation of techniques and outcomes of mitral valve repair in dogs. J Am Vet Med Assoc 2004;224:1941-1945

72. Hirao H, Hoshi K, Kobayashi M, et al: Surgical correction of subvalvular aortic stenosis using cardiopulmonary bypass in a dog. J Vet Med Sci 2004;66:559-562

73. Nelson DA, Fossum TW, Gordon S, et al: Surgical correction of subaortic stenosis via right ventriculotomy and septal resection in a dog. $J$ Am Vet Med Assoc 2004;225:705-708

74. Orton EC, Hackett TB, Mama K, et al: Technique and outcome of mitral valve replacement in dogs. J Am Vet Med Assoc 2005;226:1508-1512

75. Orton EC, Herdon GD, Boon JA, et al: Influence of open surgical correction on intermediate-term outcome in dogs with subvalvular aortic stenosis: 44 cases (1991-1998). J Am Vet Med Assoc 2000;216:364-367

76. Tanaka R, Hoshi K, Shimizu M, et al: Surgical correction of cor triatriatum dexter in a dog under extracorporeal circulation. JSAP 2003;44:370-373

77. Van der Linden PJ, De Herr SG, Belisle S, et al: Critical oxygen delivery during cardiopulmonary bypass in dogs: pulsatile vs. non-pulsatile blood flow. Eur J Anaes 2006;23:10-16

78. Akkerman JN, Runne WC, Sixma JJ, et al: Improved survival rates in dogs after extracorporeal circulation by improved control of heparin levels. J Thorac Cardiovasc Surg 1974;68:59-65

79. Gillinov AM, Redmond JM, Winkelstein JA, et al. Complement and neutrophil activation during cardiopulmonary bypass: a study in the complement-deficient dog. Ann Thorac Surg 1994; $57: 345-352$

80. Wass CT, Waggoner JR, Cable DG, et al: Selective convective brain cooling during normothermic cardiopulmonary bypass in dogs. J Thorac Cardiovasc Surg 1997:115:1350-1357 